\title{
Effects of Small-Scale Gold Mining (SGM) to Mercury and Nutrient Contents in Soil in Kokap Subdistrict, Kulonprogo, Yogyakarta
}

\author{
Rika Ernawati1, Tedy Agung Cahyadi'2, Shahensah Anand Anggian Rambe ${ }^{3}$ \\ 1,2,3 Universitas Pembangunan Nasional “Veteran” Yogyakarta, Indonesia
}

\begin{abstract}
Gold processing in Dusun Sangon, Kalirejo Village, Kokap Subdistrict, Kulonprogo Regency, Special Region of Yogyakarta Province uses amalgamation method. Mercury use in gold processing has a potential impact on environmental damage and health of organism. Therefore, management on mercury-contaminated soil is needed to reduce environmental impacts. However, before performing soil management, it is important to conduct research on initial condition of research location, including research on the soil's nutrient quality and mercury content. Testing was conducted in the laboratory. Mercury $(\mathrm{Hg})$ content testing used mercury analyzer testing method. pH testing used ISRIC $6^{\text {th }} 2002$ method. Organic carbon testing used SNI 13-4720-1998 testing method. Total nitrogen testing used SNI 2803-2010 testing method. C/N Ratio testing used SNI 134720-1998; SNI 2803-2010 testing methods. Results show that mercury contents in residual samples of gold ore and soil samples were $4.81 \mathrm{mg} / \mathrm{kg}$ and $88.63 \mathrm{mg} / \mathrm{kg}$ respectively, which were included in TC-B and TC-A in the aforementioned order. Meanwhile, mercury content in gold ore Samples 1 and 2 were $0.28 \mathrm{ppm}$ and $0.14181 \mathrm{ppm}$ respectively. Soil nutrient content parameters of Organic C, Total $\mathrm{N}$, and $\mathrm{C} / \mathrm{N}$ ratio were found to be very low. These results might be influenced by processing activities in gold ore mining.
\end{abstract}

Keywords: Small-scale gold mining, Mercury, Nutrient, Soil

This is an open access article under the CC-BY-NC license

\section{INTRODUCTION}

In Indonesia, there are 713 locations of small-scale gold mining, spreading across Java, Sumatera, Kalimantan, and Sulawesi and employing approximately 60,000 people (Aspinall, 2001). Gold mining business in Kokap region has taken place for decades, starting from the discovery of quartz veins containing gold at Sangon and its surroundings by traditional gold miners from Tasikmalaya (Setiabudi, 2005).

Gold mining in Dusun Sangon, Kalirejo Village, Kokap Subdistrict, Kulonprogo Regency, Special Region of Yogyakarta Province uses amalgamation method with mercury. Mercury is toxic heavy metal considered as one of ten primary chemicals which become primary environmental concern (WHO, 2017). Mercury usage in gold mining has potential impact on environmental damage and health of organism. Mercury in environment comes from two main sources: geogenic and anthropogenic, and has toxicity nature (Marrugo, et al., 2015).

Gold mining activities in many developing countries which uses amalgam technology causes significant mercury pollution in soil and bodies of water; this serious problem of mercury pollution also happens in developed countries (Li, et al., 2015; Cordy, et al., 2011; Drace, et al., 2012; Krisnayanti, et al., 2012). According to several studies, mercury-contaminated soil has caused significant threats to water supply, which in turn will affect agricultural output quality (Horvat, et al., 2003; Qiu, et al., 2005). Therefore, mercury-contaminated soil needs to be managed to reduce its environmental impact. However, before performing management on the contaminated soil, it is important to conduct research on its initial condition, including its nutrient quality and mercury content. The research results can then be used for consideration in choosing methods used for remediation of the contaminated soil. 


\section{RESEARCH AREA}

This study was conducted at one of small-scale gold mines at Dusun Sangon, Kalirejo Village, Kokap Subdistrict, Kulonprogo Regency, Special Region of Yogyakarta Province. It is located approximately at $50 \mathrm{~km}$ west to the City of Yogyakarta, at UTM 49 M 396664 m E 9133375 m S (Figure 1). The research location has tropical climate, with drought and rainy season occurring alternately from May to October and from November to April respectively. The research area has an average rainfall of $1430 \mathrm{~mm}$ per year, with average rainy days of 12 per month. Highest rainfall occurs in January $(689 \mathrm{~mm}$; 18 rainy days). The research area has slope steepness between $25 \%$ and $40 \%$. The regional geology of the research area is included in old andesite formation, shown in the center, north, west, and southwest of the area. The constituent lithology consists of andesite breccia with matrix of sandy tuff. Fragments consist of pyroxene andesite to andesite and horblende (Bemmelen, 1949).
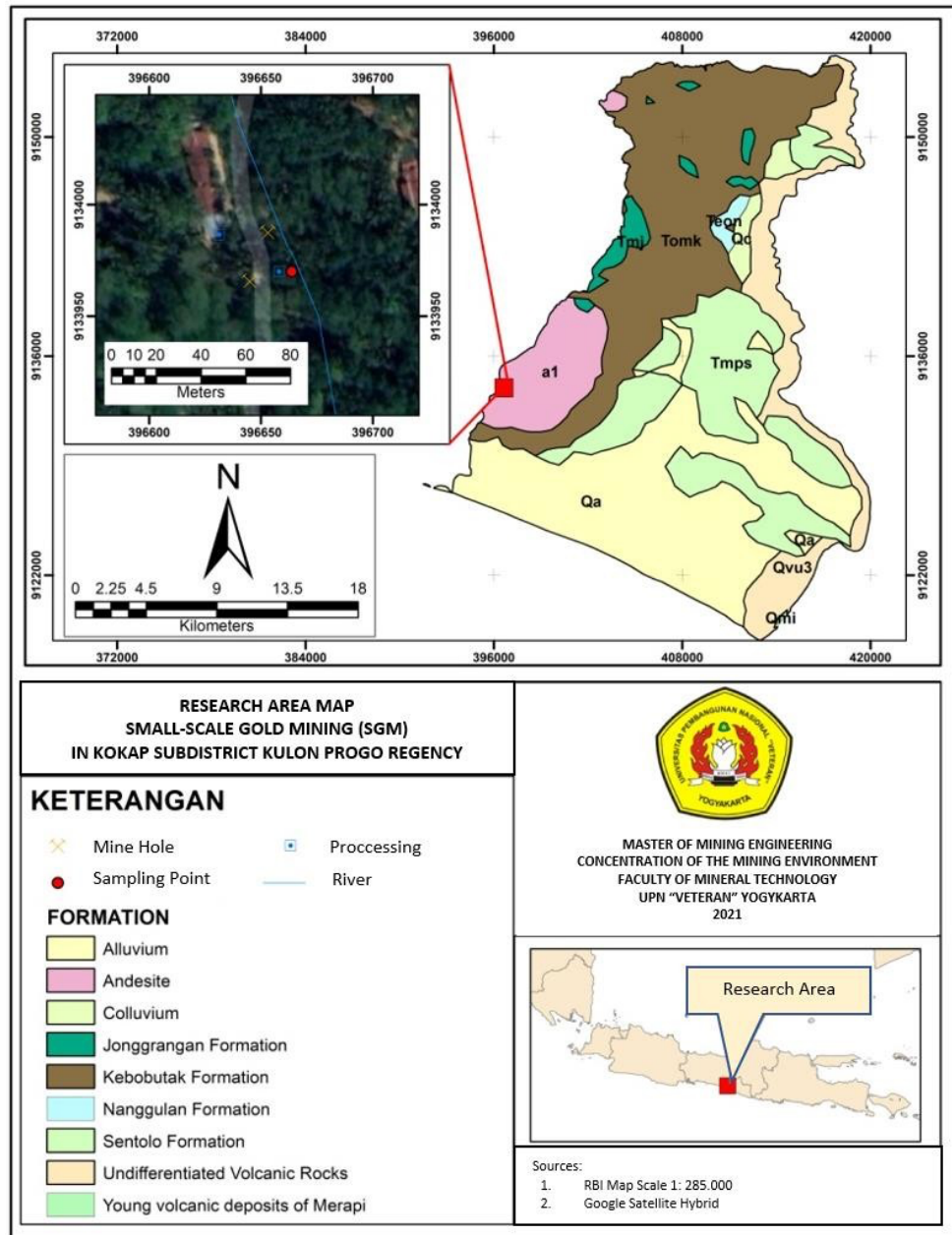

Figure 1. Research Area Map

\section{RESEARCH METHODOLOGY}

This research was conducted with purposive sampling method by taking soil samples in areas or points that allow proper representation of research location. This was done by taking two samples, consisting of sample of gold ore processing residue and soil sample from the gold processing area. Soil sampling referred to SNI 8520:2018 on the way of collection of solid hazardous and toxic (H\&T) waste. Soil samples were taken from $15 \mathrm{~cm}$ below soil level by using stainless steel hand auger (Figure 2). Then, mercury ( $\mathrm{Hg}$ ) testing was conducted by using mercury analyzer method at Integrated Research and Testing Laboratory (LPPT) of Universitas Gadjah Mada, while testing on $\mathrm{pH}$ (with ISRIC $6^{\text {th }} 2002$ method), organic carbon (with SNI 13-4720-1998 method), total nitrogen (with SNI 2803-2010 method), 
and C/N ratio (with SNI 13-4720-1998 and SNI 2803-2010 methods) were conducted at dilakukan di Center for Environmental Health Engineering and Disease Control (BBTKLPP) of Yogyakarta.

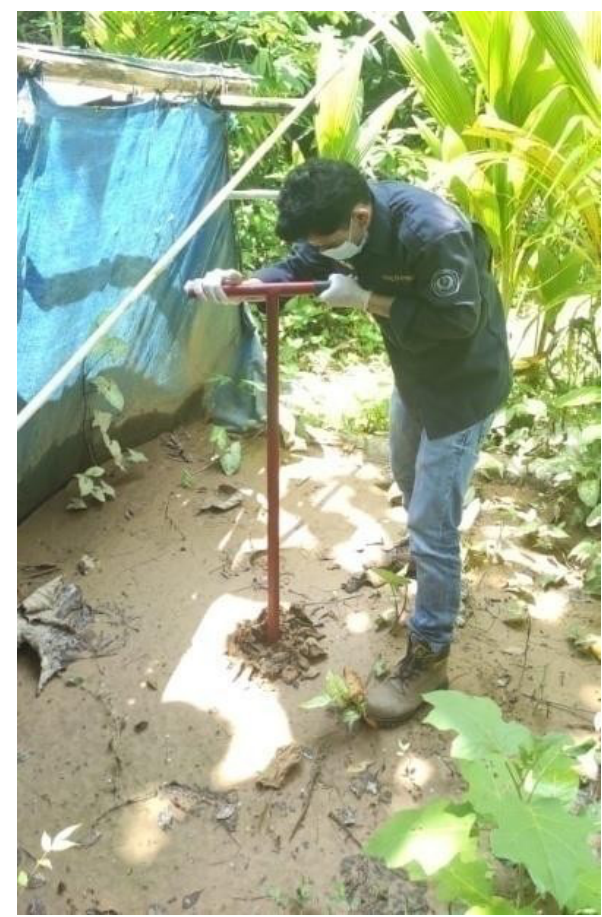

Figure 2. Soil Sample Collection

\section{RESULTS AND DISCUSSION}

\section{Mercury content in gold mines in Sangon}

Testing was conducted on two samples: sample of gold ore processing residue and soil sample by analyzing their mercury content in laboratory through mercury analyzer. The results were used to understand soil condition after gold processing with amalgamation method. Mercury content testing results were compared to the standard value of toxic characteristics through total concentration for defining the ways of management of soil contaminated with hazardous and toxic waste. The results are presented in Table 1. There are three standard values of toxic characteristics pursuant to Appendix XIII of Government Regulation No. 22 of 2021 on the Implementation of Conservation and Management of Environment as follows:

1. Should pollutant concentration found to be greater than Total Concentration "A" (TC-A), the polluted soil is managed in accordance with Category 1 of H\&T Waste Management, which includes H\&T waste with acute and direct impacts to humans and confirmable negative impacts to environment.

2. Should pollutant concentration found to be similar to or lesser than TC-A and greater than Total Concentration "B" (TC-B), the polluted soil is managed in accordance with Category 2 of H\&T Waste Management, which includes H\&T waste with delayed effects, indirect impacts to humans and environment, and sub-chronic or chronic toxicity.

3. Should pollutant concentration found to be similar to or lesser than TC-B and greater than Total Concentration "C" (TC-C), the polluted soil is managed in accordance with non-H\&T Waste Management, which is non-H\&T waste with no technical agreement, so that all technical standards are listed in environmental agreement. 
RSF Conference Series: Engineering and Technology

Vol. 1 (1), 191-197

Effects of Small-Scale Gold Mining (SGM) to Mercury and Nutrient Contents in Soil in Kokap Subdistrict,

Kulonprogo, Yogyakarta

Rika Ernawati, Tedy Agung Cahyadi, Shahensah Anand Anggian Rambe

Table 1. Mercury contents in sample ore residue and sample soil

\begin{tabular}{|c|c|c|c|c|c|c|}
\hline \multirow{2}{*}{ Samples } & \multirow{2}{*}{$\begin{array}{c}\mathrm{Hg} \\
\text { contents }\end{array}$} & \multirow{2}{*}{ Unit } & \multirow{2}{*}{ Testing method } & \multicolumn{3}{|c|}{ Standard value $(\mathrm{mg} / \mathrm{kg}$ ) } \\
\hline & & & & TC-A & TC-B & TC-C \\
\hline Ore residue & 4.81 & $\mathrm{mg} / \mathrm{kg}$ & Mercury analyzer & 300 & 75 & 0.3 \\
\hline Soil & 88.63 & & & & & \\
\hline
\end{tabular}

Mercury contents in sample ore residue and sample soil were measured to be very high, amounted to $4.81 \mathrm{mg} / \mathrm{kg}$ (TC-B) and $88.63 \mathrm{mg} / \mathrm{kg}$ (TC-A) respectively, in accordance with definition of management of soil contaminated with H\&T waste pursuant to Appendix XIII of Government Regulation No. 22 of 2021 on the Implementation of Conservation and Management of Environment.

\section{Mercury content in gold ores in Sangon}

Mercury content in gold ores in Sangon was obtained from literature study on research by Sumarjono, et al. (2019) on the mercury content in gold ores in Sangon. The results of this research were used to understand mercury content in gold ores before gold processing with amalgamation method as found in sub IV.1 was conducted. The researchers conducted testing on two samples of gold ores collected at the research area, which were called Gold Ore Sample 1 and Gold Ore Sample 2. The results of research by Sumarjono, et al. (2019) are shown in Table 2.

Table 2. Testing results of mercury content in gold ore

\begin{tabular}{ccccc} 
Parameter & Unit & \multicolumn{2}{c}{ Samples } & Testing method \\
& & Gold Ore 1 & Gold Ore 2 & \\
\hline $\mathrm{Hg}$ & $\mathrm{ppm}$ & 0.28 & 0.14181 & Mercury analyzer \\
\hline
\end{tabular}

Source: Sumarjono, et al. (2019)

The results showed that mercury contents in gold ore Samples 1 and 2 were $0.28 \mathrm{ppm}$ and $0.14181 \mathrm{ppm}$ respectively. Sangon gold ores have mercury content closely related to their mineralization process during magma differentiation process.

\section{pH, Organic Carbon, Total Nitrogen, and C/N Ratio values}

Testing was conducted on two samples: sample of gold ore processing residue and soil sample by laboratory analysis. Testing results were used to understand $\mathrm{pH}$ level of both samples and the soil sample's nutrient content after gold processing with mercury was conducted. The values of respective parameters were classified based on the results of research by Soil Research Center of the Department of Agriculture (1983). Classification results were used as guidelines in conducting the appropriate soil quality improvement and soil remediation to reduce mercury pollution impacts to the environment. Testing results show that $\mathrm{pH}$ level of gold ore residue was 8.05 which was considered neutral to slightly alkaline while soil $\mathrm{pH}$ level was 7.42 which was considered neutral. Organic-C content in both samples were considered very low, amounted to $0.30 \%$ in gold ore residue sample and $0.36 \%$ in soil sample. Mustofa (2007) in his research stated that organic matter content in soil in form of organic-C should be maintained at not less than $2 \%$, so that organic matter content in the soil does not decrease over time due to mineralization decomposition process. Meanwhile, total-N content in both samples were 
considered very low, amounted to $0.06 \%$. Results of $\mathrm{pH}$ level and soil nutrient content testing are presented in Table 3.

Table 3. Results of testing of $\mathrm{pH}$ level and organic- $\mathrm{C}$, total- $\mathrm{N}$, and $\mathrm{C} / \mathrm{N}$ ratio parameters of soil nutrient content

\begin{tabular}{ccccc}
\hline \multirow{2}{*}{ Parameters } & Unit & \multicolumn{2}{c}{ Samples } & Ore residue \\
& & Soil & Testing method \\
\hline $\mathrm{pH}$ & - & 8.05 & 7.42 & ISRIC 6 ${ }^{\text {th } 2002}$ \\
\hline Organic carbon & $\mathrm{mg} / \mathrm{kg}$ & 3022.71 & 3632.31 & SNI 13-4720-1998 \\
\hline Total nitrogen & $\mathrm{mg} / \mathrm{kg}$ & 618.682 & 627.038 & SNI 2803-2010 \\
\hline C/N ratio & - & 4.886 & 5.793 & $\begin{array}{c}\text { SNI 13-4720-1998; } \\
\text { SNI 2803-2010 }\end{array}$ \\
\hline
\end{tabular}

Source: Lab testing, 2021.

Decrease in pH level and organic matter content causes low activity of soil microbes. Soil microbes have important functions in providing nutrients for plant survivability. Soil nutrient content, with parameters of organic- $\mathrm{C}$, total- $\mathrm{N}$, and $\mathrm{C} / \mathrm{N}$ ratio were found to be very low. This could be influenced by the processing activities on gold ore mining site which uses amalgamation method (Mulyani, et al. 2021; Naiola 1997; Zulfikah, et al. 2014), so that mercury waste, the processing's residue, was collected in the tailings pond which previously came into contact with the surrounding environment of the mining site, such as soil, water, and air. Mercury impacts on soil were shown in the soil quality decrease which influenced soil nutrient parameters.

One of the most important aspects in total soil nutrient balance is the ratio of organic carbon to nitrogen ( $\mathrm{C} / \mathrm{N}$ ratio). The $\mathrm{C} / \mathrm{N}$ ratio of organic matter is the comparison between the number of carbon (C) content and the number of nitrogen $(\mathrm{N})$ content present in an organic matter. Based on the results, it is suggested that soil remediation uses phytoremediation method by combining several additives such as biochar and compost to improve nutrient quality and reduce mercury content in soil (Hidayat, 2015; Hamzah, 2012; Lestari, 2020).

\section{CONCLUSION}

Based on the research results, it can be concluded that:

1. Mercury contents in gold ore residue and soil samples were $4.81 \mathrm{mg} / \mathrm{kg}$ (TC-B) and $88.63 \mathrm{mg} / \mathrm{kg}$ (TC-A) respectively.

2. Mercury content in gold ores were significantly small compared to the result of mercury content testing on soil after gold processing activities, amounted to $0.28 \mathrm{ppm}$ and $0.14181 \mathrm{ppm}$ in gold ore Samples 1 and 2 respectively.

3. Gold ore residue sample pH level was 8.05, considered neutral to slightly alkaline, while soil sample $\mathrm{pH}$ level was 7.42, considered neutral. Organic-C content in gold ore residue and soil samples were found to be characteristically very low, amounted to $0.30 \%$ and $0.36 \%$ respectively. Meanwhile, total-N content in gold ore residue and soil samples were found to be very low, amounted to $0.06 \%$. The results show the reduction of soil quality due to gold mining activities.

\section{Acknowledgement}

The authors would like to thank the institute for Research and Community Service at Universitas Pembangunan Nasional Veteran Yogyakarta, Indonesia, for providing funds for this research. 


\section{REFERENCES}

Rika Ernawati, Tedy Agung Cahyadi, Shahensah Anand Anggian Rambe

Aspinall, C., \& Eng, P. (2001). Small-scale mining in Indonesia. International Institute for Environment and Development and the World Business Council for Sustainable Development, England.

Cordy, P., Veiga, M. M., Salih, I., Al-Saadi, S., Console, S., Garcia, O., ... \& Roeser, M. (2011). Mercury contamination from artisanal gold mining in Antioquia, Colombia: The world's highest per capita mercury pollution. Science of the Total Environment, 410, 154-160.

Drace, K., Kiefer, A. M., Veiga, M. M., Williams, M. K., Ascari, B., Knapper, K. A., ... \& Cizdziel, J. V. (2012). Mercury-free, small-scale artisanal gold mining in Mozambique: utilization of magnets to isolate gold at clean tech mine. Journal of Cleaner Production, 32, 88-95.

Hamzah, A., Kusuma, Z., Utomo, W. H., \& Guritno, B. (2012). Penggunaan tanaman Vetiveria zizanoides L. dan biochar untuk remediasi lahan pertanian tercemar limbah tambang emas. Buana Sains, 12(1), 53-60.

Hidayat, B. (2015). Remediasi tanah tercemar logam berat dengan menggunakan Biochar. Jurnal Pertanian Tropik, 2(1), 51-61.

Horvat, M., Nolde, N., Fajon, V., Jereb, V., Logar, M., Lojen, S., ... \& Drobne, D. (2003). Total mercury, methylmercury and selenium in mercury polluted areas in the province Guizhou, China. Science of the Total Environment, 304(1-3), 231-256.

Krisnayanti, B. D., Anderson, C. W., Utomo, W. H., Feng, X., Handayanto, E., Mudarisna, N., \& Ikram, H. (2012). Assessment of environmental mercury discharge at a four-year-old artisanal gold mining area on Lombok Island, Indonesia. Journal of Environmental Monitoring, 14(10), 2598-2607.

Lestari, N. D., \& Aji, A. N. (2020). PENGARUH KOMPOS DAN BIOCHAR TERHADAP FITOREMEDIASI TANAH TERCEMAR KADMIUM DARI LUMPUR LAPINDO MENGGUNAKAN KANGKUNG DARAT. Jurnal Tanah dan Sumberdaya Lahan, 7(1), 167-176.

Li, L., Flora, J. R., Caicedo, J. M., \& Berge, N. D. (2015). Investigating the role of feedstock properties and process conditions on products formed during the hydrothermal carbonization of organics using regression techniques. Bioresource technology, 187, 263-274.

Marrugo-Negrete, J., Durango-Hernández, J., Pinedo-Hernández, J., Olivero-Verbel, J., \& Díez, S. (2015). Phytoremediation of mercury-contaminated soils by Jatropha curcas. Chemosphere, 127, 58-63.

Mulyani, S., Zahrah, S., \& Sulhaswardi, S. (2021). ANALISIS KANDUNGAN UNSUR HARA DAN TOTAL MIKROBA TANAH BEKAS PENAMBANGAN EMAS TANPA IZIN (PETI) DARI BEBERAPA KECAMATAN KABUPATEN KUANTAN SINGINGI. Jurnal Agroteknologi, 11(2), 67-74.

Mustofa, A. (2007). Perubahan Sifat Fisik, Kimia, dan Biologi Tanah Pada Hutan Alam yang Diubah Menjadi Lahan Pertanian di Kawasan Taman Nasional Gunung Leuser. [Skripsi]. Fakultas Kehutanan. Institut Pertanian Bogor, Bogor.

Naiola, B. P. (1997). PENGARUH PENAMBANGAN EMAS TRADISIONAL TERHADAP STATUS HARA LAHAN HUTAN PRIMER BOJONG PARI, SUKABUMI. Berita Biologi, 4(1), 21-25.

Qiu, G., Feng, X., Wang, S., \& Shang, L. (2005). Mercury and methylmercury in riparian soil, sediments, mine-waste calcines, and moss from abandoned Hg mines in east Guizhou province, southwestern China. Applied Geochemistry, 20(3), 627-638.

Setiabudi, B.T., (2005). Penyebaran Merkuri Akibat Usaha Pertambangan Emas Di Daerah Sangon, Kabupaten Kulon Progo, Propinsi D.I. Yogyakarta, Kolokium Hasil Lapangan, Direktorat Inventarisasi Sumberdaya Mineral/DIM 2005.

SNI 8520 : 2018. Tentang "Cara Pengambilan Contoh Uji Limbah B3 Padat".

Sumarjono, E., Nusanto, G., \& Suyono, U. S. (2019). Merkuri Dalam Bijih Emas Di Dusun Sangon II Kalirejo Kokap Kulonprogo Daerah Istimewa Yogyakarta.

Van Bemmelen, R.W. (1949). The Geology ofIndonesia. Vol IA, Government PrintingOffice, hal. 28-29, 102-106, 595-602.

WHO. (2017). Ten chemicals of major public health concern. World Health Organization. 
RSF Conference Series: Engineering and Technology

Vol. 1 (1), 191-197

Effects of Small-Scale Gold Mining (SGM) to Mercury and Nutrient Contents in Soil in Kokap Subdistrict,

Kulonprogo, Yogyakarta

Rika Ernawati, Tedy Agung Cahyadi, Shahensah Anand Anggian Rambe

Zulfikah, Z., Basir, M., \& Isrun, B. (2014). Konsentrasi merkuri (Hg) dalam tanah dan jaringan tanaman kangkung (Ipomoea Reptans) yang diberi bokashi kirinyu (Chromolaena Odorata L.) pada limbah tailing penambangan emas poboya kota palu (Doctoral dissertation, Tadulako University). 